\title{
STUDIES IN SCARLET FEVER
}

\section{Studies Concerning the Blanching Phenomenon in SCARLET FEVER ${ }^{1}$}

\author{
BY KONRAD E. BIRKHAUG
}

(From the Medical Clinics of the Johns Hopkins Hospital and Sydenham Hospital, Baltimore)

(Received for publication, November 3, 1924)

THE RELATION OF STREPTOCOCCUS HEMOLYTICUS TO SCARLET FEVER

As early as 1895, Marmorek (1) recognized the frequency with which the Streptococcus hemolyticus was present in the throat secretions from scarlet fever patients and inclined towards the belief that this organism might be the possible etiological factor in the production of the disease. Consequently, he prepared an antistreptococcic serum against scarlet fever by immunizing animals with polyvalent strains of Streptococcus hemolyticus isolated from the throat secretions of scarlet fever patients in the acute stage of the disease. Unfortunately, clinical trials with the serum boded ill for its success and it was soon forgotten. Eight years later, Tavel and Aronson (2) and Moser (3) re-examined Marmorek's work and attempted to improve the latter's method of serum production. Moser, in particular, adhered to the belief, that Streptococcus hemolyticus associated with scarlet fever, possessed certain specific characteristics, foreign to the streptococci usually found in other general septic conditions. This belief was not based either on cultural or on serological findings. Moser made a logical advance, however, in that he immunized a horse with strains of Streptococcus hemolyticus, isolated directly from the blood of fatal malignant cases of scarlet fever. He inoculated the live organisms directly into the horse, for fear that "certain specific characteristics" of these organisms might be destroyed or altered by carrying them through the usual laboratory procedures. Very promising clinical trials with this serum were reported by Moser (3), Schick (4), and a

1 Read before the Medical Society of the Johns Hopkins Hospital, May 19, 1924. 
number of observers (5). The results were particularly impressive in the severer toxic cases, admitted to the hospital with doubtful prognosis.

It was noted that ten to fifteen hours following an intramuscular injection of $200 \mathrm{cc}$. of the serum, there was a rapid abatement in the toxic manifestations, a striking and critical fall of the temperature, prompt improvement in the rate and quality of the pulse, and rapid disappearance of the cyanosis with cessation of diarrhea and chills. It was apparent to Schick (4), that the serum "worked essentially like an antitoxic serum and most strikingly in purely toxic cases." Difficulty arose in preserving the serum, and that combined with the frequency of serum sickness, contributed to its unenthusiastic reception and limited use.

More recently attention has been focussed on the significance of Streptococcus hemolyticus in scarlet fever and already an enormous literature has accumulated on this subject. The works of Tunnicliffe (6), Bliss (7), Stevens (8), Gordon (9), Dochez and Shermann (10), and Dochez (11), are notable in this respect. They have observed that Streptococcus beta hemolyticus, isolated from the throats of scarlet fever patients, is a specific type of streptococcus, most readily distinguishable by agglutination and the phenomenon of agglutinin absorption, from the types of Streptococcus hemolyticus giving rise to angina and septic conditions in general. Dick and Dick (12) working on this theory that a certain strain of Streptococcus hemolyticus was the specific cause of scarlet fever, swabbed a strain of this organism, isolated from a case of scarlet fever, on the tonsils of a human volunteer. This resulted in what they interpreted as a mild attack of scarlet fever.

Dochez (11) has recently succeeded in producing a scarlatinal anti-streptococcic serum by immunizing a horse with the specific type of Streptococcus beta hemolyticus found in the throats of scarlet fever patients, and has observed that this serum is capable of blanching the scarlet fever rash locally, in a more conspicuous manner than the serum of patients convalesing from scarlet fever. The results obtained from its use by Blake, Trask and Lynch (13), indicate that the serum may possess distinct diagnostic and therapeutic value.

Through the kindness of Dr. Dochez it has been possible to use the 
specific immune serum, which he has sent us, to study the blanching phenomenon in scarlet fever. During these investigations, it has seemed desirable to re-examine the ability of $(a)$ normal human serum and $(b)$ convalescent scarlet fever serum to blanch the scarlet fever rash; $(c)$ to determine the exact time at which the serum from patients convalescing from scarlet fever developed the power to blanch the scarlet fever rash and $(d)$ to compare these results with the rash extinction phenomenon obtained with Dochez's serum.

\section{THE SCHULTZ-CHARLTON PHENOMENON}

Schultz and Charlton (14) in 1918 first observed that intracutaneous injections of 0.5 to $1 \mathrm{cc}$. of serum from normal persons or from persons convalescent from scarlet fever caused a definite blanching of the rash in patients with scarlet fever. The blanching phenomenon occurred within five to six hours following the serum injection and the areas blanched measured from 2.5 to $5 \mathrm{~cm}$. in diameter. They found in a series of fifty typical cases of scarlet fever, that positive blanching reactions were obtained in forty-four, or 88 per cent, that doubtful reactions occurred in five, or 10 per cent and that there was no blanching in one or 2 per cent. The areas blanched were found to persist until the general exanthem had faded. A few years later, Neumann (15) confirmed these observations, and noted that serum withdrawn from patients during the first four days of an attack of scarlet fever, did not produce the blanching phenomenon. Hainiss (16) found in a series of nineteen cases tested with convalescent serum, that positive blanching reactions were obtained in eleven, or 58 per cent. At this time, Paschen (17) reported the results of a series of seventy-one cases tested with convalescent serum, in which positive blanching reactions were obtained in sixty-two, or 87 per cent.

The following year, Schultz (18) re-examined his earlier work and likewise confirmed the findings of Neumann. He had observed positive blanching reactions with convalescent serum in 100 per cent of scarlet fever patients tested on the second day of the disease, in 78 per cent tested on the third day of the disease and in 60 per cent of five cases each, tested on the first and the fourth day of the disease. Cases tested on the fifth day of the disease gave uniformly negative results. At this time, Tron (19) reported the results of fifty cases of scarlet fever tested with convalescent serum in various stages of the disease and observed the blanching phenomenon in only ten, or 21 per cent.

Hazelhorst (20) in 1921, obtained in a series of fifty definite cases of scarlet fever the Schultz-Charlton phenomenon in 80 per cent and reported that the tests were consistently negative in thirteen cases of other eruptive diseases. At this time, Steinkopf (21) found in a series of forty-nine cases of undoubted scarlet fever that positive blanching reactions occurred in 83.7 per cent. Furthermore, 
Mulsow (22) reported a series of thirty cases of scarlet fever tested intradermally with convalescent serum withdrawn from scarlet fever patients from twenty-one to twenty-eight days after the appearance of the rash; he obtained positive blanching reactions in $\mathbf{5 3}$ per cent and doubtful reactions in 10 per cent. In a second series of twenty cases tested intradermally with normal human serum, positive blanching reactions were obtained in 40 per cent and doubtful reactions in 15 per cent. He also noted that serum from normal persons failed to produce the Schultz-Charlton phenomenon in about 60 per cent of definite cases of scarlet fever.

Rojo (23) in 1922 tested eighteen cases of scarlet fever with convalescent serum and obtained positive blanching reactions in 78 per cent. Raymond (24) found in a series of seventy-two cases of definite scarlet fever that intradermal injections of normal human serum produced the blanching phenomenon in 82 per cent. Meyer-Estorf (25) made the observation that the Schultz-Charlton phenomenon was best elicited on the second day after the appearance of the rash. Toomey and Nourse (26) tested fourteen cases of scarlet fever with normal human serum, using $0.5 \mathrm{cc}$. doses, and obtained positive blanching reactions in nine cases, or 64 per cent. The same number of cases were tested with convalescent serum, using $0.5 \mathrm{cc}$. doses, and obtained positive blanching reactions in only three cases, or 21 per cent. In a second series of twenty-seven cases, using $1 \mathrm{cc}$. doses, with normal human serum they obtained positive blanching reactions in twenty-one cases, or 81 per cent and with convalescent serum they obtained positive blanching reactions in seventeen cases, or 63 per cent. Attention was called to the fact that a higher percentage of positive results can be obtained with the larger doses of serum. Blum (27) tested sixty-four cases of scarlet fever with varying amounts of serum, in an effort to show that the extent of the rash extinction was not dependent on the amount injected. The results of this work were inconstant and subject to great variations. Table 4 shows the results of the Schultz-Charlton phenomenon by other workers, together with a summary of the results of the work reported in this paper.

In reviewing the literature that has accumulated concerning the Schultz-Charlton phenomenon one finds a difference of opinion as regards the value of this test. On the one hand Neuman is inclined to regard it as a specific diagnostic phenomenon while on the other Tron considers it worthless in the diagnosis of doubtful cases of scarlet fever. In a series of closely allied investigation in scarlet fever, it seemed desirable to re-examine the blanching phenomenon with normal human serum and convalescent scarlet fever serum in order that these studies might be compared with the results obtained with the Dochez scarlatinal antistreptococcic serum. 


\section{The blanching phenomenon with normal human serum}

In order to test the ability of normal human serum to produce the Schultz-Charlton phenomenon, blood was withdrawn from six healthy individuals, whose past histories revealed no attack of scarlet fever or other general septic conditions caused by Streptococcus hemolyticus, and whose Wassermann reactions were negative. The blood was placed in the ice-box for 12 to 18 hours, the serum then drawn off, heated for an hour at $56^{\circ} \mathrm{C}$. and stored in the ice-box in sealed tubes. To the tubes 0.3 per cent solution of tricresol was added.

Nine cases of scarlet fever were tested intradermally with doses of 1 and $0.5 \mathrm{cc}$. of this serum during the first four days after the appearance of the rash. The results of these tests are shown in table 1. Of the total nine cases, five patients showed definite blanching of the rash at the site of injection on the second and third day of the disease, while two patients showed a slight or suspicious blanching reaction when tested on the second day of the disease. The greatest incidence of rash extinctions occurred on the second day of the rash, and of six patients tested on this day, four showed definite blanching. Seven patients were tested on the third day of the rash; in one only did a positive blanching reaction occur, though in one other patient a suspicious rash extinction was noted. The results were consistently negative when the tests were made on the fourth day of the rash.

The areas blanched were usually regular in outline round or oval in shape, measuring from 1 to $6.5 \mathrm{~cm}$. in diameter. Some, however, were less sharply delimited, having irregular and indefinite edges with numerous stellate projections, varying in size from 5 to $9 \mathrm{~cm}$. in diameter. The shortest interval between the injection of serum and the occurrence of definite blanching at the site of injection was five hours, and the longest interval fourteen hours. The blanching reaction usually persisted until the disappearance of the general rash. In the areas blanched on the second day of the rash, no pigmentation or desquamation was observed, while on the third day of the rash yellow-brownish pigmentation persisted in the skin and disappeared with the general desquamation. It was found that the area blanched was directly dependent on the amount of serum injected and that while $1 \mathrm{cc}$. of serum produced a definite blanching reaction, $0.5 \mathrm{cc}$. failed to extinguish the rash in the same patient. Nine control tests with horse serum and diphtheria anti-toxin gave consistently negative results. Injections of epinephrin in solutions of 1:1,000 and 1:5,000 did not produce the blanching phenomenon. 
TABLE 1

Rash extinction results from intradermal injections of normal human serum

\begin{tabular}{|c|c|c|c|c|c|c|}
\hline $\begin{array}{c}\text { CASE } \\
\text { SUYBER }\end{array}$ & $\begin{array}{c}\text { DAY OF } \\
\text { RASB }\end{array}$ & $\begin{array}{l}\text { DOSE OF } \\
\text { SEROM } \\
\text { INJECTED }\end{array}$ & RESULTS & $\begin{array}{l}\text { BLANCHENG } \\
\text { TnEE }\end{array}$ & $\begin{array}{c}\text { AREA } \\
\text { BLANCEED }\end{array}$ & APPEARANCE OP AREA \\
\hline 1 & $\begin{array}{l}3 \\
4\end{array}$ & $\begin{array}{l}c c . \\
0.5 \\
1.0 \\
0.5 \\
1.0\end{array}$ & $\begin{array}{l}+ \\
+ \\
0 \\
0\end{array}$ & $\begin{array}{c}\text { hours } \\
6 \\
5\end{array}$ & $\begin{array}{l}\mathrm{cm} . \\
1.6 \\
2.4\end{array}$ & $\begin{array}{l}\text { Regular, round } \\
\text { Regular, round }\end{array}$ \\
\hline 2 & $\begin{array}{l}2 \\
3\end{array}$ & $\begin{array}{l}0.5 \\
1.0 \\
0.5 \\
1.0\end{array}$ & $\begin{array}{l}+ \\
+ \\
0 \\
0\end{array}$ & $\begin{array}{l}9 \\
9\end{array}$ & $\begin{array}{l}1.2 \\
3.6\end{array}$ & $\begin{array}{l}\text { Regular, round } \\
\text { Regular, round }\end{array}$ \\
\hline 3 & $\begin{array}{l}2 \\
3\end{array}$ & $\begin{array}{l}0.5 \\
1.0 \\
0.5 \\
1.0\end{array}$ & $\begin{array}{l}0 \\
? \\
0\end{array}$ & 11 & 4.2 & Irregular, stellate \\
\hline 4 & 4 & $\begin{array}{l}0.5 \\
1.0\end{array}$ & $\begin{array}{l}0 \\
0\end{array}$ & & & \\
\hline 5 & 4 & $\begin{array}{l}0.5 \\
1.0\end{array}$ & $\begin{array}{l}0 \\
0\end{array}$ & & & \\
\hline 6 & $\begin{array}{l}2 \\
3\end{array}$ & $\begin{array}{l}0.5 \\
1.0 \\
0.5 \\
1.0\end{array}$ & $\begin{array}{l}+ \\
+ \\
0 \\
?\end{array}$ & $\begin{array}{r}8 \\
6 \\
11\end{array}$ & $\begin{array}{l}1.0 \\
2.5 \\
6.5\end{array}$ & $\begin{array}{l}\text { Regular, round } \\
\text { Regular, round } \\
\text { Irregular, stellate }\end{array}$ \\
\hline 7 & $\begin{array}{l}2 \\
3\end{array}$ & $\begin{array}{l}0.5 \\
1.0 \\
0.5 \\
1.0\end{array}$ & $\begin{array}{l}0 \\
+ \\
0 \\
0\end{array}$ & 12 & 2.4 & Regular, oval \\
\hline 8 & $\begin{array}{l}2 \\
3\end{array}$ & $\begin{array}{l}0.5 \\
1.0 \\
0.5 \\
1.0\end{array}$ & $\begin{array}{l}+ \\
+ \\
0 \\
0\end{array}$ & $\begin{array}{l}8 \\
8\end{array}$ & $\begin{array}{l}1.5 \\
5.1\end{array}$ & $\begin{array}{l}\text { Regular, round } \\
\text { Regular, round }\end{array}$ \\
\hline 9 & $\begin{array}{l}2 \\
3\end{array}$ & $\begin{array}{l}0.5 \\
1.0 \\
0.5 \\
1.0\end{array}$ & $\begin{array}{l}0 \\
?\end{array}$ & 14 & 2.4 & Regular, round \\
\hline
\end{tabular}

Total cases, 9; positive blanching in five cases, or 56 per cent; suspicious blanching in two cases, or 23 per cent. 


\section{The blanching phenomenon with convalescent scarlet fever serum}

In order to compare the blanching power of normal human serum with that of convalescent scarlet fever serum blood was withdrawn from scarlet fever patients twenty to forty days after the initial appearance of the rash. The convalescent serum was prepared in the same way as the normal human serum, pooled and the mixture of convalescent sera used for the following tests, the results of which are shown in table 3. A total of sixty-five intradermal injections were made in forty-two cases of scarlet fever during the first four days of the rash. The amount of serum injected varied from 0.1 to $1 \mathrm{cc}$. In a series of nineteen patients, it was found that when convalescent serum was injected intradermally during the first fifty hours after the initial appearance of the rash, the blanching phenomenon was positive in seventeen cases, or 89 per cent, and slight or suspicious after rubbing the injected area, in one case, or 5 per cent. In eight cases the injections were made sixty hours after the initial appearance of the rash. The blanching phenomenon was positive in seven of these, or 87 per cent and slight or suspicious after rubbing the injected area, in one or 13 per cent. In twenty-eight cases intradermal injection of convalescent serum seventy hours after the initial appearance of the rash, did not produce any effect upon the rash.

The blanched area in the positive cases varied from 1 to $4 \mathrm{~cm}$. in diameter, the size depending directly on the amount of the convalescent serum injected into the skin. In numerous instances the blanching was just perceptible and the outline indefinite; in others the blanched area was sharply delimited, round or oval and stood out in sharp contrast to the surrounding erythematous skin. While $1 \mathrm{cc}$. of convalescent serum produced a definite blanching reaction, 0.5 and $0.1 \mathrm{cc}$. failed to extinguish the rash in the same individual and therefore the percentage of positive blanching reactions was greater with the larger doses than with the smaller amounts of serum injected. This was also observed in the reactions obtained with normal serum.

After the blanching had persisted forty to sixty hours, there appeared, as a rule, a yellowish-brown pigmentation about the site of injection, which was shortly followed by a fine, powdery-like desquamation. This peeling differed from the general desquamation which was scaly, the skin peeling off in large flakes. In most instances the blanching occurred between seven and twelve hours after the injection of the serum and persisted until the disappearance of the general rash. 
Fifty control tests were made with 0.1 to $1 \mathrm{cc}$. of diphtheria antitoxin or normal horse serum. These sera were injected intradermally in forty-one cases from the first to the fourth day of the rash. In no instance was the rash blanched by these control sera. Convalescent scarlet fever serum failed to produce the blanching phenomenon in five cases of erysipelas, three cases of measles and four cases of rubella.

Initial appearance of antitoxic substance in the blood serum of scarlet fever patients. In an effort to determine the exact time at which

TABLE 2

Results of tests to determine the time at which serum of patients convalescing from scarlet fever attains the power of blanching the exonthem

\begin{tabular}{|c|c|c|c|c|c|c|c|c|c|c|c|c|c|c|c|c|}
\hline \multirow[b]{2}{*}{$\begin{array}{c}\text { CASE } \\
\text { NUMRBR }\end{array}$} & \multirow[b]{2}{*}{$\mathbf{A G E}$} & \multirow[b]{2}{*}{$\begin{array}{c}\text { DAY OP } \\
\text { RASB }\end{array}$} & \multirow{2}{*}{$\begin{array}{c}\text { DOSE } \\
\text { OF } \\
\text { SERUM }\end{array}$} & \multicolumn{12}{|c|}{$\begin{array}{c}\text { SERIES OF CONVALESCENT SCARLET FEVER SERA DURING THE } \\
\text { FRST TWENE DAYS OF THE DISEASE, } \\
\text { INJECTED IN TEN CASES OF SCARLET FEVER }\end{array}$} & \multirow{2}{*}{$\begin{array}{c}\underset{\text { TMEE }}{\text { OF }} \\
\text { BLANCH- } \\
\text { NVG, } \\
\text { AVER- } \\
\text { AGE }\end{array}$} \\
\hline & & & & 窎 & $=1$ & & f & & & & 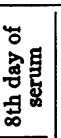 & 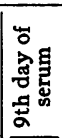 & 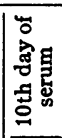 & 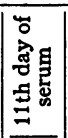 & 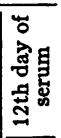 & \\
\hline & & & $c c$. & & & & & & & & & & & & & hours \\
\hline 1 & 3 & 2 & 0.5 & 0 & 0 & 0 & 0 & 0 & 0 & 0 & + & + & + & & + & 11 \\
\hline 2 & 13 & 2 & 0.5 & 0 & 0 & 0 & 0. & 0 & 0 & 0 & 0 & + & + & + & + & 9 \\
\hline 3 & 20 & 2 & 0.5 & 0 & 0 & 0 & $?^{*}$ & 0 & 0 & 0 & 0 & 0 & 0 & + & + & 9 \\
\hline 4 & 5 & 2 & 5 & 0 & 0 & 0 & 0 & 0 & 0 & 0 & 0 & 0 & + & + & + & 7 \\
\hline 5 & 6 & 2 & 0.5 & 0 & 0 & 0 & 0 & 0 & 0 & 0 & 0 & 0 & + & + & + & 10 \\
\hline 6 & 4 & 2 & 5 & 0 & 0 & 0 & 0 & 0 & 0 & 0 & 0 & + & + & & + & 12 \\
\hline 7 & 8 & 2 & 0.5 & 0 & 0 & 0 & 0 & 0 & 0 & 0 & 0 & 0 & + & + & + & 7 \\
\hline 8 & 8 & 2 & 0.5 & & & & & & & 0 & 0 & 0 & 0 & + & $t$ & 10 \\
\hline 9 & 8 & 2 & 0.5 & & & & & & & 0 & 0 & 0 & + & + & + & 7 \\
\hline 10 & 11 & 2 & 0.5 & & & & & & & 0 & 0 & 0 & + & + & + & 8 \\
\hline
\end{tabular}

Total cases, 10; power to produce the blanching phenomenon first observed in the eighth day serum in one case, or 10 per cent, in the ninth day serum in three cases, or $\mathbf{3 0}$ per cent, in the tenth day serum in eight cases, or 80 per cent, in the eleventh and twelfth day sera in all cases, or 100 per cent.

* Suspicious blanching, followed by pigmentation and fine desquamation.

the blood serum from patients with scarlet fever develop the capacity to blanch the rash in scarlet fever, blood was withdrawn daily from a series of scarlet fever patients from the second to the twelfth day of the disease. The serum was prepared in the same manner as that described in the experiments with normal human serum. The results of these tests are shown in table 2. In a series of ten cases of scarlet fever tested with intradermal injections of the above-mentioned sera, 
the first definite rash extinction reaction occurred with the serum withdrawn on the eighth day after the appearance of the rash. This occurred in only one case. The serum withdrawn on the ninth day of the disease caused definite blanching reactions in three cases and the serum obtained on the tenth day of the disease produced the blanching phenomenon in eight cases. The serum withdrawn on the eleventh and twelfth days produced definite blanching in all of ten cases. A slight or suspicious blanching reaction occurred on the fourth day of the disease, but this instance was consequently ruled out, since no blanching occurred in the same patient with serum withdrawn between the fifth and tenth days. The areas of rash extinction about the site of injection measured about $2.5 \mathrm{~cm}$. in diameter and resembled in general those obtained with convalescent serum. The areas blanched by the sera removed on the eighth, ninth and tenth days of the disease were inconstant and frequently faded twenty-four hours after the initial appearance of the blanching, while the areas blanched by the sera obtained on the eleventh and twelfth days were much more striking and persisted until the disappearance of the general rash.

\section{The blanching phenomenon with Dochez's scarlatinal antistreptococcic serum}

During the past nine months, ninety-four intradermal tests have been made with Dochez's scarlatinal antistreptococcic serum in a series of fifty-seven cases of scarlet fever. These patients were tested during the first four days of the rash. The results are tabulated in table 3. The amount of serum injected varied from 0.1 to $1 \mathrm{cc}$. Forty cases of scarlet fever were tested within the first sixty hours after the appearance of the rash. Dochez's serum produced the SchultzCharlton rash extinction phenomenon in all of these, or 100 per cent. Ten cases were tested seventy hours after the appearance of the rash; in only one of these, or in 10 per cent did the definite blanching phenomenon, occur, while in three or 30 per cent suspicious blanching was observed. When the test was performed eighty hours after the appearance of the exanthem, blanching, with one possible exception, was never observed.

Case no. 6 (table 3) afforded a striking and instructive example of 
TABLE 3

Rask extinction results from intradermal injections of Dochez's scarlatinal antistreptococcic serum and convalescent scarlet fever serum in early cases of scarlet fever

\begin{tabular}{|c|c|c|c|c|c|c|c|c|c|}
\hline \multirow[b]{2}{*}{$\underset{\text { xuserser }}{\text { CAsE }}$} & \multirow[b]{2}{*}{ AGE } & \multirow[b]{2}{*}{$\begin{array}{c}\text { DAY OY } \\
\text { RASB }\end{array}$} & \multirow[b]{2}{*}{$\begin{array}{c}\text { APPROXI- } \\
\text { MATE } \\
\text { HOURS }\end{array}$} & \multirow[b]{2}{*}{ DOSE } & \multicolumn{5}{|c|}{ RESULTS } \\
\hline & & & & & Dochez & $\begin{array}{l}\text { Conva- } \\
\text { lescent }\end{array}$ & Control & $\begin{array}{c}\text { Blanching } \\
\text { time }\end{array}$ & $\begin{array}{c}\text { Diameter } \\
\text { of } \\
\text { blanching } \\
\text { (Dochez's) }\end{array}$ \\
\hline & & & & $c c$. & & & & hours & $\mathrm{cm}$. \\
\hline 1 & 15 & 2 & 40 & 0.5 & + & + & 0 & 9 & 6.0 \\
\hline 2 & 11 & 3 & 70 & 0.5 & 0 & 0 & 0 & & \\
\hline 3 & 33 & 3 & 70 & 0.5 & 0 & 0 & 0 & & \\
\hline 4 & 3 & 2 & 46 & 0.5 & + & + & 0 & 11 & 8.5 \\
\hline 5 & 21 & 3 & 70 & 0.5 & 0 & 0 & 0 & & \\
\hline \multirow[t]{8}{*}{6} & 9 & 2 & 35 & 0.5 & + & + & 0 & 9 & 7.5 \\
\hline & & & & 0.2 & + & + & 0 & 9 & 4.8 \\
\hline & & 3 & 60 & 0.5 & + & + & 0 & 12 & 5.0 \\
\hline & & & & 0.2 & + & 0 & 0 & 14 & 3.5 \\
\hline & & & 70 & 0.5 & + & 0 & 0 & 16 & 4.0 \\
\hline & & & & 0.2 & + & 0 & 0 & 17 & 2.4 \\
\hline & & 4 & 80 & 0.5 & 0 & 0 & 0 & & \\
\hline & & & & 0.2 & 0 & 0 & & & \\
\hline 7 & 13 & 2 & 40 & 0.5 & + & + & 0 & 14 & 7.0 \\
\hline \multirow[t]{2}{*}{8} & 4 & 4 & 80 & 1.0 & 0 & 0 & 0 & & \\
\hline & & & & 0.5 & 0 & 0 & & & \\
\hline 9 & 22 & 3 & 70 & 0.5 & ?* & 0 & 0 & 7 & 8.0 \\
\hline 10 & 20 & 2 & 45 & 0.5 & + & + & 0 & 8 & 4.0 \\
\hline \multirow[t]{2}{*}{11} & 10 & 3 & 70 & 1.0 & 0 & 0 & 0 & & \\
\hline & & & & 0.5 & 0 & 0 & & & \\
\hline \multirow[t]{2}{*}{12} & 6 & 3 & 70 & 1.0 & ?* & 0 & 0 & 11 & 9.8 \\
\hline & & & & 0.5 & 0 & 0 & & & \\
\hline \multirow[t]{2}{*}{13} & 9 & 3 & 70 & 1.0 & o & 0 & 0 & & \\
\hline & & & & 0.5 & 0 & 0 & & & \\
\hline \multirow[t]{2}{*}{14} & 6 & 3 & 70 & 1.0 & 0 & 0 & 0 & & \\
\hline & & & & 0.5 & 0 & 0 & & & \\
\hline 15 & 5 & 2 & 40 & 0.5 & + & + & 0 & 16 & 4.6 \\
\hline 16 & 6 & 3 & 60 & 0.5 & + & $?^{*}$ & 0 & 15 & 9.0 \\
\hline 17 & 6 & 2 & 35 & 0.5 & + & + & 0 & 12 & 4.8 \\
\hline \multirow[t]{2}{*}{18} & 8 & 3 & 55 & 1.0 & + & + & 0 & 8 & 9.2 \\
\hline & & & & 0.5 & + & + & 0 & 9 & 4.6 \\
\hline 19 & 4 & 2 & 40 & 0.5 & + & + & 0 & 14 & 6.8 \\
\hline 20 & 8 & 2 & 45 & 0.5 & + & + & 0 & 17 & 4.4 \\
\hline 21 & 2 & 2 & 40 & 0.5 & + & + & 0 & 16 & 11.2 \\
\hline \multirow{3}{*}{22} & 12 & 2 & 30 & 0.5 & + & + & 0 & 12 & 7.5 \\
\hline & & & & 0.2 & + & ?* & & 12 & 4.2 \\
\hline & & & & 0.1 & + & 0 & & 12 & 2.6 \\
\hline 23 & 9 & 2 & 40 & 0.5 & + & + & 0 & 9 & 9.1 \\
\hline
\end{tabular}


KONRAD E. BIRKHAUG

TABLE 3-Continued

\begin{tabular}{|c|c|c|c|c|c|c|c|c|c|}
\hline \multirow[b]{2}{*}{$\begin{array}{c}\text { CASE } \\
\text { NOUBRER }\end{array}$} & \multirow[b]{2}{*}{ AGE } & \multirow[b]{2}{*}{$\begin{array}{c}\text { DAY OY } \\
\text { RASB }\end{array}$} & \multirow[b]{2}{*}{$\begin{array}{c}\text { APPROXI- } \\
\text { MATI } \\
\text { HOURS }\end{array}$} & \multirow[b]{2}{*}{ DOSE } & \multicolumn{5}{|c|}{ RESULTS } \\
\hline & & & & & Dochez & $\begin{array}{l}\text { Conva- } \\
\text { lescent }\end{array}$ & Control & $\begin{array}{l}\text { Blanching } \\
\text { time }\end{array}$ & $\begin{array}{l}\text { Diameter } \\
\text { of } \\
\text { blanching } \\
\text { (Dochez's) }\end{array}$ \\
\hline \multirow{4}{*}{$\begin{array}{l}24 \\
25\end{array}$} & \multirow[b]{2}{*}{9} & \multirow[b]{2}{*}{2} & \multirow[b]{2}{*}{45} & \multirow{2}{*}{$\begin{array}{c}c c . \\
0.5\end{array}$} & \multirow[b]{2}{*}{+} & \multirow[b]{2}{*}{ ?* } & \multirow[b]{2}{*}{0} & \multirow{2}{*}{$\begin{array}{l}\text { hours } \\
11\end{array}$} & \multirow{2}{*}{$\begin{array}{l}\mathrm{cm} . \\
7.0\end{array}$} \\
\hline & & & & & & & & & \\
\hline & \multirow[t]{2}{*}{15} & \multirow[t]{2}{*}{3} & \multirow[t]{2}{*}{60} & 1.0 & + & + & \multirow[t]{2}{*}{0} & 12 & 7.3 \\
\hline & & & & 0.5 & + & 0 & & 12 & 3.2 \\
\hline \multirow[t]{2}{*}{26} & \multirow[t]{2}{*}{3} & \multirow[t]{2}{*}{4} & 90 & 1.0 & 0 & 0 & 0 & & \\
\hline & & & & 0.5 & 0 & 0 & & & \\
\hline 27 & 4 & 4 & 85 & 1.0 & 0 & 0 & 0 & & \\
\hline & & & & 0.5 & 0 & 0 & 0 & & \\
\hline 28 & 20 & 3 & 60 & 0.5 & + & + & 0 & 12 & 9.0 \\
\hline 29 & 8 & 4 & 90 & 1.0 & 0 & 0 & 0 & & \\
\hline & & & & 0.5 & 0 & 0 & 0 & & \\
\hline 30 & 13 & 3 & 52 & 0.5 & + & + & 0 & 13 & 5.4 \\
\hline 31 & 33 & 2 & 30 & 0.5 & + & + & 0 & 14 & 7.2 \\
\hline & & & & 0.2 & + & + & 0 & 14 & 3.8 \\
\hline & & & & 0.1 & + & 0 & 0 & 14 & 2.3 \\
\hline 32 & 3 & 1 & 22 & 0.5 & + & + & 0 & 16 & 3.2 \\
\hline & & & & 0.2 & + & & & 16 & 1.7 \\
\hline & & & & 0.1 & + & & & 16 & 1.3 \\
\hline 33 & 24 & 3 & 50 & 0.4 & + & & 0 & 18 & 5.0 \\
\hline & & & & 0.2 & + & & & 18 & 4.2 \\
\hline 34 & 8 & 2 & 34 & 0.4 & + & & 0 & 9 & 4.0 \\
\hline 35 & 13 & 3 & 55 & 0.4 & + & + & 0 & 11 & 7.6 \\
\hline 36 & 8 & 2 & 36 & 0.3 & + & 0 & 0 & 7 & 5.4 \\
\hline 37 & 30 & 2 & 40 & 0.4 & + & & 0 & 9 & 4.0 \\
\hline 38 & 11 & 4 & 80 & 0.5 & ?* & 0 & 0 & 16 & 6.4 \\
\hline 39 & 7 & 2 & 38 & 0.4 & + & & 0 & 7 & 7.2 \\
\hline 40 & 4 & 5 & 100 & 1.0 & 0 & & & & \\
\hline & & & & 0.5 & 0 & & & & \\
\hline 41 & 3 & 3 & 56 & 0.5 & + & & & 8 & 7.0 \\
\hline 42 & 10 & 2 & 42 & 0.5 & + & & & 7 & 9.2 \\
\hline & & & & 0.2 & + & & & 7 & 4.0 \\
\hline & & & & 0.1 & + & & & 7 & 2.3 \\
\hline 43 & 5 & 5 & 100 & 1.0 & 0 & & & & \\
\hline & & & & 0.5 & 0 & & & & \\
\hline 44 & 12 & 2 & 38 & 0.5 & + & & & 9 & 9.0 \\
\hline & & & & 0.1 & + & & & 9 & 2.4 \\
\hline 45 & 11 & 3 & 50 & 1.0 & + & + & & 11 & 8.3 \\
\hline & & & & 0.5 & + & + & & 11 & 5.2 \\
\hline $\int 46$ & 3 & 3 & 55 & 0.5 & + & + & 0 & 14 & 7.4 \\
\hline & & & & 0.1 & + & 0 & & 14 & 1.6 \\
\hline
\end{tabular}


TABLE 3-Concluded

\begin{tabular}{|c|c|c|c|c|c|c|c|c|c|}
\hline \multirow[b]{2}{*}{$\begin{array}{c}\text { CASE } \\
\text { NURBer }\end{array}$} & \multirow[b]{2}{*}{ AGE } & \multirow[b]{2}{*}{$\begin{array}{c}\text { DAY OP } \\
\text { RASH }\end{array}$} & \multirow[b]{2}{*}{$\begin{array}{l}\text { APPOXXI- } \\
\text { YATE } \\
\text { HOURS }\end{array}$} & \multirow[b]{2}{*}{ DOSE } & \multicolumn{5}{|c|}{ RESULTS } \\
\hline & & & & & Dochez & $\begin{array}{l}\text { Conva- } \\
\text { lescent }\end{array}$ & Control & $\begin{array}{c}\text { Blanching } \\
\text { time }\end{array}$ & $\begin{array}{l}\text { Diameter } \\
\text { blanching } \\
\text { (Dochez's) }\end{array}$ \\
\hline \multirow{4}{*}{47} & & & & cc. & & & & hours & $\mathrm{cm}$. \\
\hline & 13 & 1 & 14 & 0.5 & + & & & 6 & 6.1 \\
\hline & & & & 0.2 & + & & & 6 & 3.3 \\
\hline & & & & 0.1 & + & & & 9 & 1.6 \\
\hline \multirow[t]{2}{*}{48} & 15 & 3 & 56 & 1.0 & + & & & 12 & 5.6 \\
\hline & & & & 0.5 & + & & & 12 & 2.0 \\
\hline \multirow[t]{2}{*}{49} & 6 & 3 & 60 & 0.5 & + & & & 13 & 3.2 \\
\hline & & & & 0.2 & + & & & 13 & 1.4 \\
\hline \multirow[t]{2}{*}{50} & 7 & 3 & 55 & 1.0 & + & & & 9 & 3.0 \\
\hline & & & & 0.2 & 0 & & & & \\
\hline 51 & 11 & 4 & 90 & 1.0 & 0 & 0 & & & \\
\hline 52 & 6 & 4 & 90 & 1.0 & 0 & 0 & & & \\
\hline 53 & 8 & 2 & 30 & 0.5 & + & + & & 9 & 4.7 \\
\hline 54 & 6 & 2 & 40 & 0.5 & + & + & & 11 & 6.4 \\
\hline 55 & 23 & 2 & 46 & 0.5 & + & & & 7 & 4.9 \\
\hline 56 & 10 & 2 & 35 & 0.3 & + & & & 9 & 7.1 \\
\hline \multirow[t]{2}{*}{57} & 39 & 3 & 70 & 1.0 & $0^{*}$ & 0 & & & \\
\hline & & & & 0.5 & 0 & & & & \\
\hline
\end{tabular}

* Suggestive blanching after rubbing the area injected.

the blanching phenomenon, following intradermal injections of equivalent doses of convalescent serum and Dochez's serum, during the second, third and fourth day of the disease. A comparative study of twenty intradermal injections was made in this patient. When doses of 0.5 and $0.2 \mathrm{cc}$. of convalescent serum and Dochez's serum were injected intradermally about 35 hours after the onset of the rash, positive blanching reactions were obtained within nine hours following the injections, the size of the areas blanched varying directly with the amount of serum injected. A dose of $0.5 \mathrm{cc}$. of Dochez's serum produced a blanched area measuring $7.5 \mathrm{~cm}$. in diameter, and a smaller dose of $0.2 \mathrm{cc}$. blanched an area measuring only $4.8 \mathrm{~cm}$. in diameter. Sixty hours after the onset of the rash, positive blanching reactions occurred both with convalescent serum and Dochez's serum with a dose of $0.5 \mathrm{cc}$. within 12 hours after the injection, and the area blanched measured $5 \mathrm{~cm}$. in diameter with Dochez's serum and only $2.6 \mathrm{~cm}$. with the convalescent serum. With a dose of $0.2 \mathrm{cc}$. of convalescent 
serum, no blanching reaction was obtained 60 hours after the appearance of the rash, while the same dose of Dochez's serum continued to produce the blanching phenomenon within fourteen hours following the injection, the area blanched measuring $3.5 \mathrm{~cm}$. in diameter. Seventy hours after the onset of the rash, similar doses of 0.5 and 0.2 cc. of convalescent serum and Dochez's serum were injected intradermally. Injections made with convalescent serum failed entirely to produce the blanching reaction while Dochez's serum produced positive reactions within 17 hours after injections of 0.5 and $0.2 \mathrm{cc}$. doses, the former dose producing a blanched area measuring $4 \mathrm{~cm}$. in diameter and the latter dose an area measuring $2.4 \mathrm{~cm}$. in diameter. Eighty hours after the onsct of the rash tests made with convalescent serum and Dochez's serum were consistently negative.

A noticeable difference was observed in the size of the areas blanched with normal human serum, convalescent scarlet fever serum and Dochez's serum (fig. 1), when the same amount of serum was injected intradermally, in three situations, in close proximity one to the other. There appeared simultaneously at the site of the three injections, within nine hours, three definitely blanched areas, regularly edged and circular in shape, but of different sizes. The area blanched by the normal human serum measured $2.2 \mathrm{~cm}$. in diameter, the area blanched by the convalescent serum $2.4 \mathrm{~cm}$. in diameter and the area blanched by the Dochez serum measured $4.8 \mathrm{~cm}$. in diameter. These tests were repeated sixty hours after the onset of the rash when doses of 0.2 cc. were injected intradermally. Fourteen hours following the injection, there appeared a definite rash extinction in the area injected with Dochez's serum, regular in outline and circular in shape, measuring $4 \mathrm{~cm}$. in diameter. No reaction was noted in the areas injected with normal human serum and convalescent scarlet fever serum.

As was noted by Blake, Trask and Lynch (13) no pigmentation or desquamation was observed during convalescence in the areas blanched within twenty-four hours after the appearance of the exanthem. When the tests were made on the succeeding days of the disease, there was noted during convalescence a faint yellowish-brown discoloration over the blanched area, which often desquamated in fine, powdery-like fragments before general desquamation occurred. 


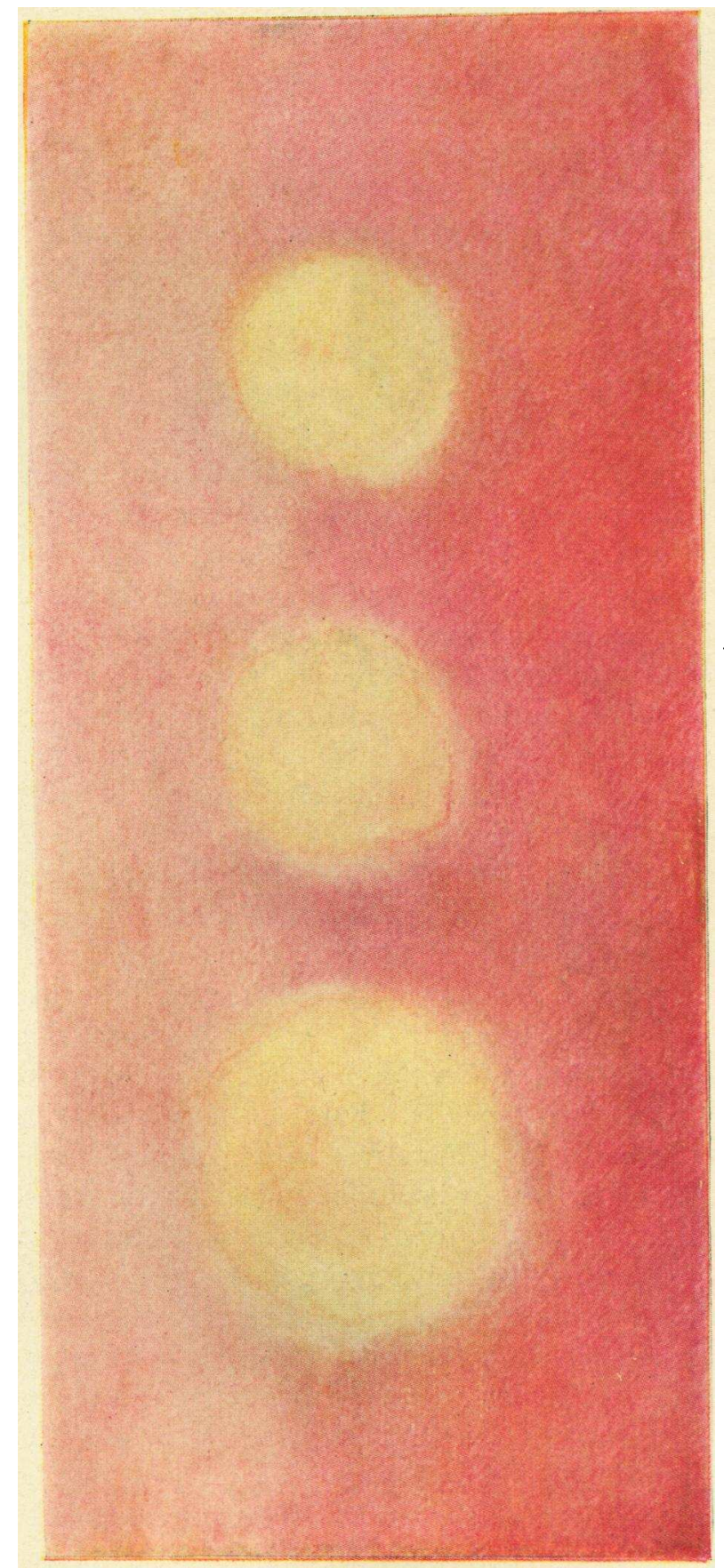

Fig. 1. Areas of Blanching Following Intradermai. Injections of $0.2 \mathrm{CC}$. of (top) Normal Human Serum; (middle) Convalescent Scarlet Fever Serum and (bottom) Dochez's Scarlatinal Antistreptococcic Serum, Nine Hours after Injection 
The areas blanched by Dochez's serum presented a great variety of shapes. Most of them were regular, round or oval and sharply accentuated by the surrounding erythematous skin. Frequently the areas were irregular showing finger-like projections (figs. 2 to 5). The tips of these extensions seemed to fol-

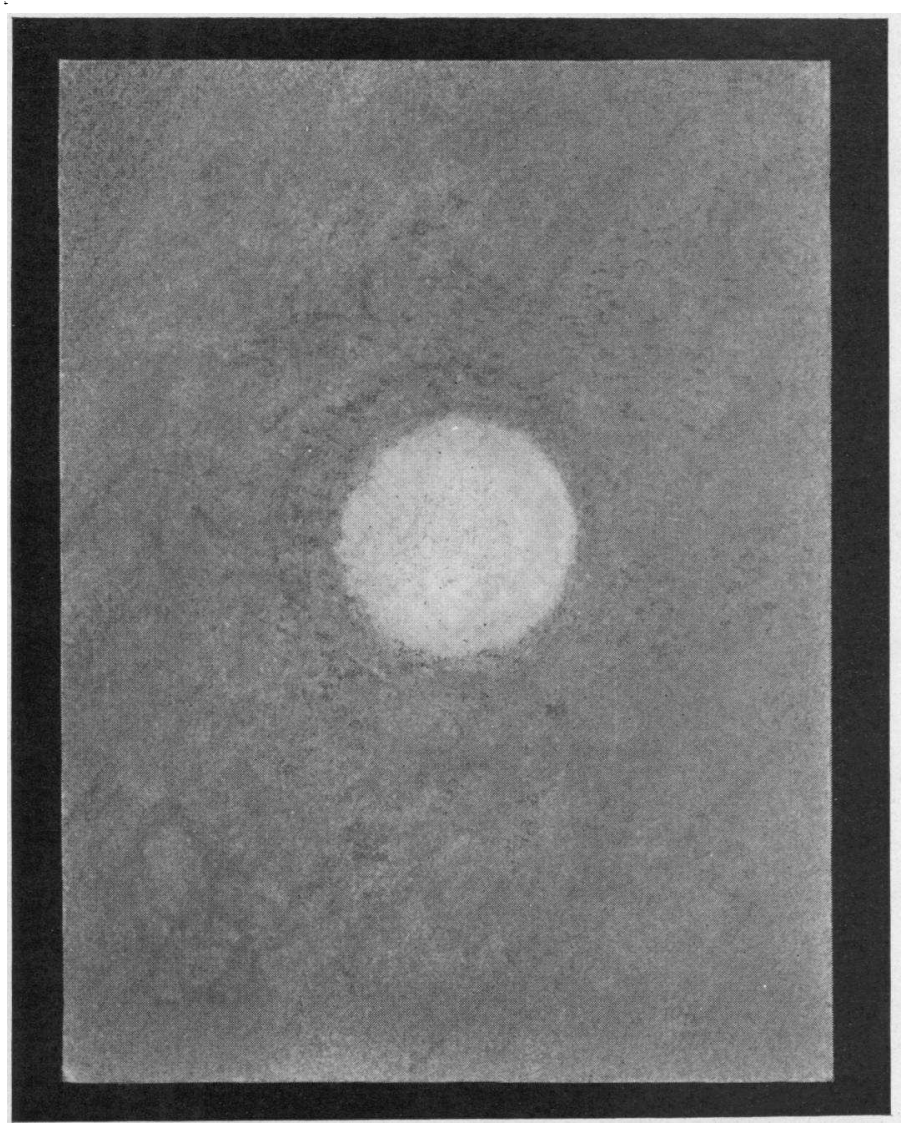

Fig. 2. Area of Blanching Following Intradermal Injection of 0.5 CC. of Dochez's Scarlatinal Antistreptococcic Serum, Eleven Hours

\section{AFTERWARDS}

low the course of the lymphatics and often measured 9 to $12 \mathrm{~cm}$. in their longest diameter. The blanching phenomenon usually reached its height fifteen to twenty-four hours after the injection of the serum. The area of blanching varied from 2.3 to $11.2 \mathrm{~cm}$. in diameter, the size depending directly on the amount of 
the serum injected into the skin and the duration of the rash. The shortest interval between the intradermal injection of Dochez's serum and the appearance of blanching was 6 hours and the longest interval 18 hours.

About 80 per cent of the rash extinction tests persisted until the disappearance of the general rash. Fifty-one control tests were made

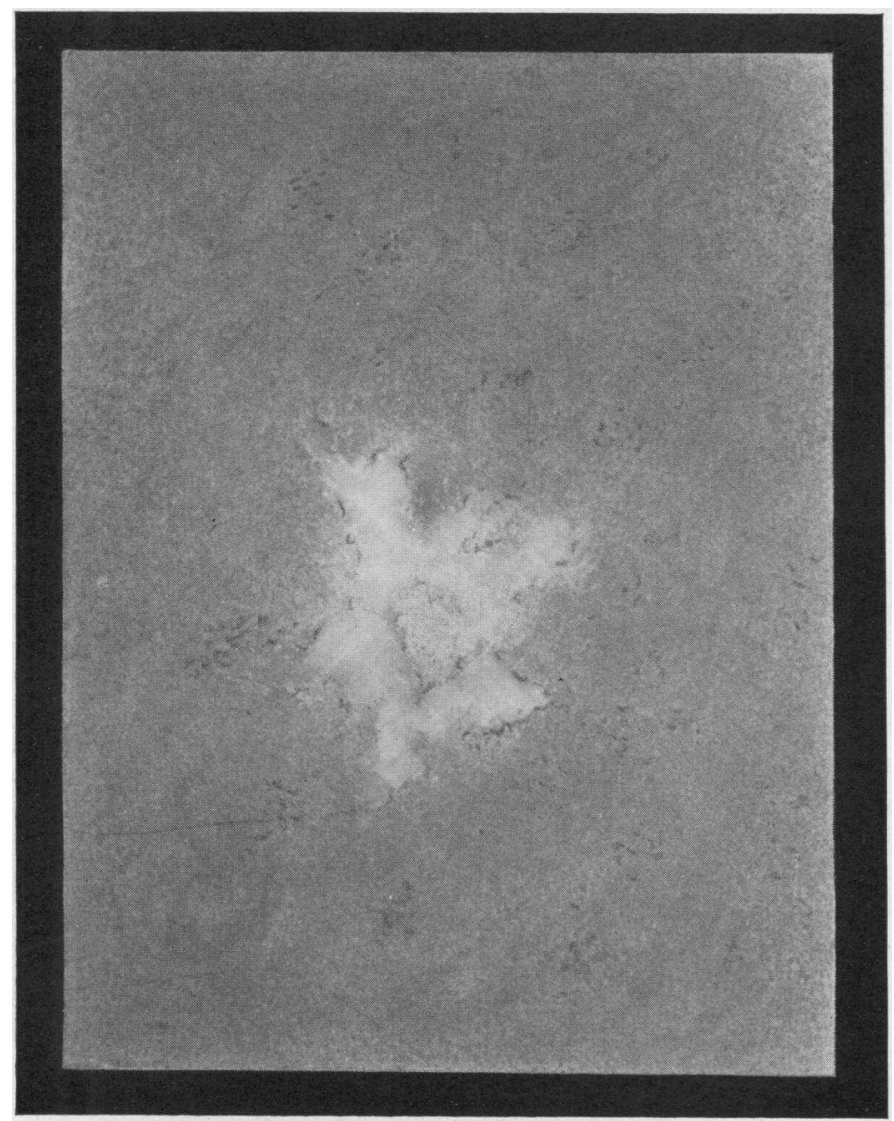

Fig. 3. Same Area Thirteen Hours After Injection

intradermally with equivalent amounts of diphtheria anti-toxin and normal horse serum. In no instance was the rash blanched by these control sera. Dochez's serum failed to produce the blanching phenomenon in seven cases of erysipelas, four cases of measles and six cases of rubella. 
Pseudo-reaction. A peculiar reaction occurred in case no. 12 (table 3) tested intradermally with Dochez's serum seventy hours after the appearance of the exanthem. The amount of serum injected was $1 \mathrm{cc}$. Twelve hours following the injection, there appeared in the area

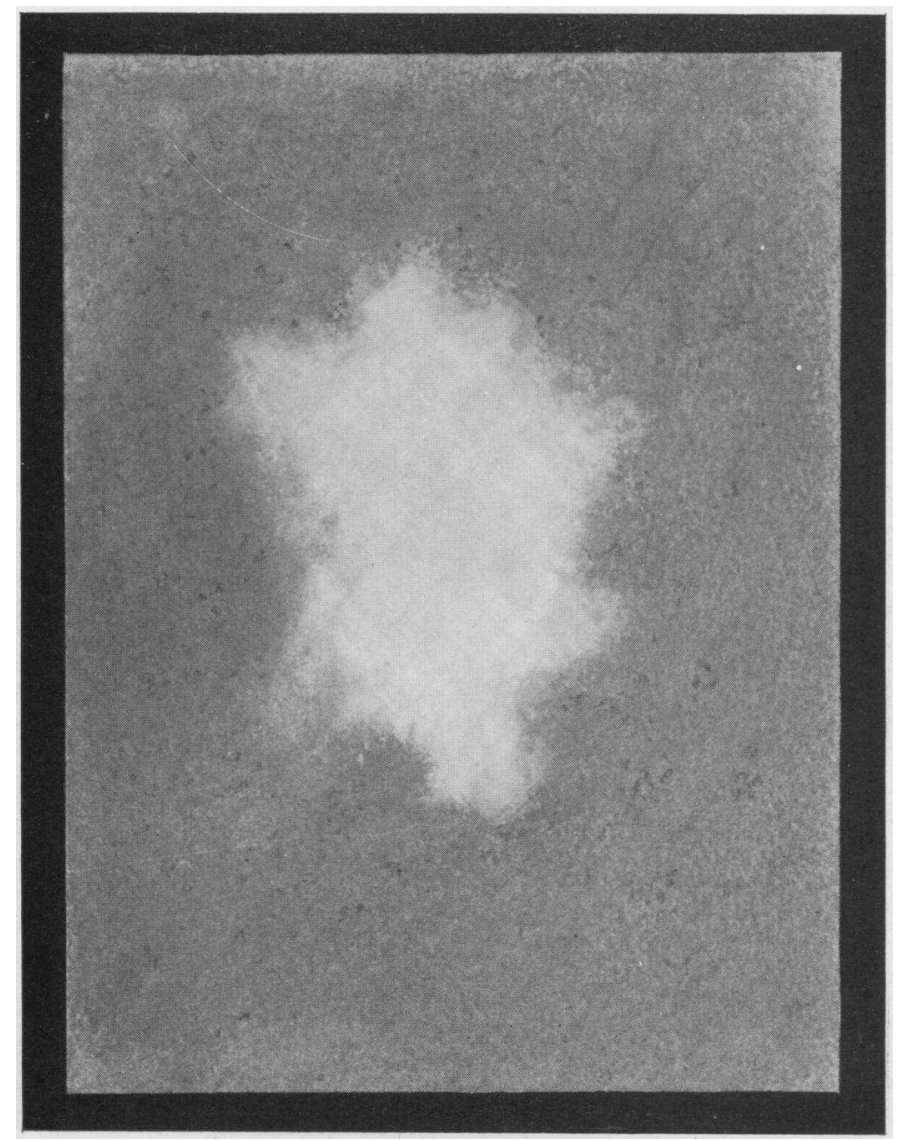

Fig. 4. Same Area Eighteen Hours after Injection

injected an intense erythema followed by marked hyperemia in the underlying skin. The redness rapidly extended in all directions, until twenty-six hours following the injection it attained a diameter of 9.8 $\mathrm{cm}$. with a definite red margin, slightly raised above the surface of the surrounding skin. At this time a definite zone of blanching was 
observed along the edges of the erythematous area, slowly working its way towards the center of this area. Forty-eight hours after the injection of the serum, the central erythema was faded and the entire area appeared definitely blanched. Vesiculation of the surface epithe-

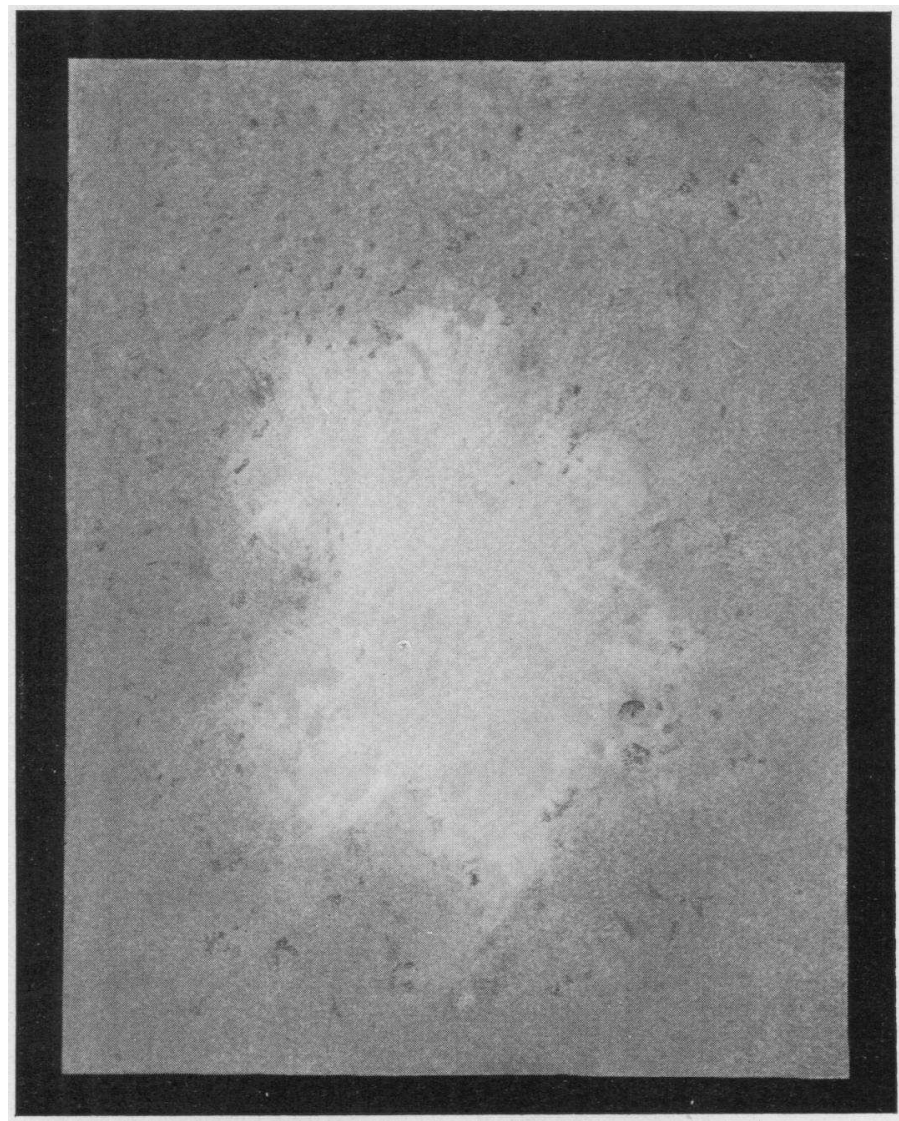

Fig. 5. Same Area Twenty-Four Hours after Injection

lium in this area was observed on the following day. No residual pigmentation was noted after the disappearance of the general rash. The combined reaction in this case strongly suggested a local hypersensitiveness to the non-toxic proteins of the horse serum, the effect of which at first prevented the blanching phenomenon. 


\section{DISCUSSION}

These observations are confirmatory of previous work and show further that Dochez's antistreptococcic serum possesses similar properties to those contained in normal human serum and convalescent scarlet fever serum. The blanching phenomenon was obtained in this series with great regularity during the first and second day after the appearance of the rash, when intradermal tests were made with normal human serum, convalescent scarlet fever serum and Dochez's serum in scarlet fever patients. An important quantitative difference was noted between strength of normal and convalescent serum and of Dochez's serum, for while normal serum and convalescent serum failed to produce the blanching phenomenon after the second day of the rash, Dochez's serum continued to blanch the exanthem until the fourth day of the rash. It was likewise observed that the blanching phenomenon was best obtained on the second day after the initial appearance of the rash, and rapidly diminished during the third day, until the capacity to blanch the rash was completely lost on the fourth day of the rash. This occurrence, one might venture to explain, is occasioned by an hypothetical specific toxin so fixed in the tissues, following a certain time of exposure to the disease, that it is not readily neutralized by the hypothetical antitoxic substance present in the normal human serum, convalescent scarlet fever serum or Dochez's serum. Considerable importance and therapeutic value may be attached to the difference in potency of blanching properties contained in these three sera in producing the Schultz-Charlton rash extinction phenomenon during the second and third day of the disease, and this difference may serve to establish a rough quantitative measure of specific antitoxic capacities contained in each of these three sera. It is apparent that Dochez's serum not only produces the rash extinction phenomenon later in the disease than the other two sera, but that it also blanches considerable larger areas of rash than does either the normal human serum or the convalescent serum. These results indicate that Dochez's serum contains the same specific substance which is demonstrable in the normal human serum and convalescent scarlet fever serum but that Dochez's serum possesses this specific property in a much greater concentration, than is demonstrable in either normal human serum or convalescent serum. 
It was, furthermore, demonstrated that the blood serum of scarlet fever patients acquired the capacity to blanch the rash in scarlet fever about the eighth day after the onset of the disease. This indicates, in so far as may be ascertained by clinical methods, that sufficient antitoxic substance is produced in the body at this stage of

TABLE 4

Results of the Schultz-Charlton phenomenon by other workers

\begin{tabular}{|c|c|c|c|c|c|}
\hline AUTHOR & 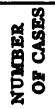 & DOSES & $\begin{array}{c}\text { CONVALESCENT } \\
\text { SERUY }\end{array}$ & $\mid \begin{array}{l}\text { NOR- } \\
\text { MAL } \\
\text { SERUM }\end{array}$ & DOCHEZ'S SERUM \\
\hline & & $c c$. & per cent & $\begin{array}{l}\text { per } \\
\text { cent }\end{array}$ & per cent \\
\hline Schultz-Charlton (15) . . . . . . . & 50 & $0.5-1.0$ & 88 & & \\
\hline Hainiss, E. (16) . . . . . . . . . & 19 & $0.5-1.0$ & 58 & & \\
\hline Paschen, E. (17) ............. & 71 & $0.5-1.0$ & 87 & & \\
\hline Schultz, W. (18)............. & & $0.5-1.0$ & $\begin{array}{l}78(3 d) \\
60(4 d)\end{array}$ & & \\
\hline Tron, G. (19) . . . . . . . . . . & 50 & $0.5-1.0$ & 21 & & \\
\hline Hazelhorst, G. (20) . . . . . . . . & 50 & $0.5-1.0$ & 80 & & \\
\hline Steinkopf, C. (21) . . . . . . . & 49 & $0.5-1.0$ & 83.7 & & \\
\hline Mulsow, F. W. (22). & 30 & $0.5-1.0$ & 53 & 10 & \\
\hline Roio, D. T. (23) . . . & 18 & $0.5-1.0$ & 78 & \pm 0 & \\
\hline Raymond, H. (24) . . . . . . . . & 72 & $0.5-1.0$ & 82 & & \\
\hline & 14 & $0.5-1.0$ & 21 & 64 & \\
\hline & 27 & 1.0 & 63 & 81 & \\
\hline Toomey and Nourse (26) . . . . . . & 8 & 0.5 & 0 & 50 & \\
\hline & 8 & 1.0 & 50 & 63 & \\
\hline & 18 & 1.0 & $\cdot$ & 100 & \\
\hline Blum, J. (27) . . . . . . . . . & 10 & 0.5 & 60 & & \\
\hline Blake, Trask, Lynch (13). & 13 & $0.02-0.5$ & & & 100 \\
\hline & 9 & $0.5-1.0$ & & 67 & \\
\hline Birkhaug, K. E... & 27 & $0.2-1.0$ & 89 & & \\
\hline & 57 & $0.2-1.0$ & & & $\begin{array}{r}100 \text { (60 hours) } \\
40 \text { (70 hours) } \\
0 \text { ( } 80 \text { hours })\end{array}$ \\
\hline
\end{tabular}

the disease to be detected in the circulating blood. It is important to note that this is simultaneous with the onset of convalescence and the return of the blood-picture to normal, which suggests strongly that the toxic substance is neutralized completely by the antitoxic substance, which at this time occurs in such excess in the circulating 
blood of the patient that the serum is capable of producing the Schultz-Charlton rash extinction phenomenon upon the scarlet fever rash of other patients.

\section{SUMMARY}

1. Serum from normal persons, without history of scarlet fever or general septic infections, produced the Schultz-Charlton rash extinction phenomenon in four of six cases tested on the second day of the rash and in one of seven cases tested on the third day of the rash.

2. Serum from convalescent scarlet fever patients produced the Schultz-Charlton rash extinction phenomenon in twenty-four of twenty-seven cases tested, or 89 per cent, during the first sixty hours of the rash but did not cause blanching seventy hours after the appearance of the rash.

3. Dochez's serum produced the Schultz-Charlton rash extinction phenomenon in forty cases, or 100 per cent, during the first sixty hours of the rash. It continued to produce blanching seventy hours after the appearance of the rash, but did not blanch eighty hours after the appearance of the rash. This indicates that Dochez's serum possesses the same specific property that is found in normal and convalescent serum but contains this specific property in considerably greater concentration.

4. Blood serum from scarlet fever patients first showed the property of producing the Schultz-Charlton rash extinction phenomenon about the eighth day of the disease.

5. Epinephrin, normal horse serum and diphtheria antitoxin failed consistently to produce the Schultz-Charlton rash extinction phenomenon in scarlet fever.

6. Normal human serum, convalescent scarlet fever serum and Dochez's serum failed consistently to produce blanching reactions in other eruptive diseases.

7. Rash extinction areas were directly proportional in size to the amount of serum injected.

The author wishes to acknowledge his indebtedness to Dr. H. L. Amoss for his kind assistance and valuable criticism in all the phases of these studies and to Dr. B. Macgowan for the privilege of making these investigations at Sydenham Hospital. 


\section{BIBLIOGRAPHY}

1. Marmorek, A. Ann. Inst. Pasteur, 1895, ix, 593. Compt. rend. Soc. biol., $1895,230$.

2. Aronson, H. Berl. klin. Wchnschr., 1902, xxxix, 979.

3. Moser. Wien. klin. Wchnschr., 1902, xv, 1053.

4. Schick. Handb. d. Kinderh., 1910, ii, 173.

5. Escherich. Wien. klin. Wchnschr., 1903, xxiii, 663.

Garlippe. Med. Klinik., 1905, li, 810.

Moltschanoff. Jahrb. f. Kinderh., 1907, lxiv, 572.

6. Tunnicliffe, Ruth. Jour. Amer. Med. Ass., 1924, lxxxii, 265.

7. Bliss, W. P. Bull. Johns Hopkins Hosp., 1920, xxxi, 173.

8. Stevens, F. A. Proc. Soc. f. Exper. Biol. \& Med., 1923, xxi, 39.

9. Gordon, M. H. Brit. Med. Jour., 1921, i, 632.

10. Dochez, A. R., and Shermann, Lillian. Jour. Amer. Med. Ass., 1924, lxxxii, 542.

11. Dochez, A. R. Proc. Soc. Exper. Biol. \& Med., 1924, xxi, 184.

12. Dick, G. F., and Dick, Gladys. Jour. Amer. Med. Ass., 1924, lxxxii, 301; Jour. Amer. Med. Ass., 1924, lxxxii, 1246.

13. Blake, F. G., Trask, J. D., and Lynch, J. F., Jour. Amer. Med. Ass., 1924, lxxxii, 712.

14. Schultz and Charlton. Ztschr. f. Kinderh., 1918, xvii, 328.

15. Neumann. Deutsch. med. Wchnschr., 1920, xlvi, 566.

16. Hainiss, E. Monatschr. f. Kinderh., 1919, xv, 523.

17. Paschen, E. Dermat. Wchnschr., 1919, lxviii, 342.

18. Schultz, W. Acta. Med. Scand., 1919, liv, 49.

19. Tron, G. Riforma med., 1921, xxxvii, 55.

20. Hazelhorst, G. München. med. Wchnschr., 1922, lxix, 116.

21. Steinkopf, C. Ztschr. f. Kinderh., 1921, xxxi, 132.

22. Mulsow, F. W. Jour. Infect. Dis., 1921, xxix, 557.

23. Rojo, D. J. Semana méd., 1922, 1, 776; Abstract Jour. Amer. Med. Ass., 1922, lxxix, 594.

24. Raymond, H. Schweiz. med. Wchnschr., 1921, li, 719.

25. Meyer-Estorf. Med. Klin, 1921, xvii, 526.

26. Toomey and Nourse. Amer. Jour. Dis. Child., 1924, xxvii, 95.

27. Blum, J. München. Med. Wchnschr., 1922, lxix, 466. 